\title{
ANNOTATEd ChECKLIST OF THE MARINE AND COASTAL BIRDS OF LEBANON
}

\author{
Ghassan Ramadan-Jaradi \\ National Council for Scientific Research, P.O.Box 118281, Beirut, Lebanon \\ Faculty of Science, Lebanese University, Hadath, Lebanon \\ grjaradi@cnrs.edu.lb
}

(Received January 2019 - Accepted January 2020)

\begin{abstract}
Ramadan-Jaradi, G. (2020). Annotated Checklist of the Marine and Coastal Birds of Lebanon. Lebanese Science Journal, 21(1), 37-53.

The study of marine and coastal birds in the Lebanon recorded 75 species along the shore line of Lebanon and for a distance of $7 \mathrm{kms}$ offshore. Of those species, 35 are seabird species, 38 marine or seawater/freshwater coastal birds, and 2 waterbird species wintering on the archipelagoes of Mina/Tripoli in North Lebanon (Grey Heron and Little Egret) with apparently much affinity to seawater in the winter season. This study highlighted 3 globally threatened species (Leach's Storm Petrel Hydrobates leucorhoa [Vulnerable], Mediterranean Yelkouan Shearwater Puffinus yelkouan [Vulnerable], and Dalmatian Pelican Pelecanus crispus [Vulnerable]), underlined 7 globally Near Threatened avian species, pointed out to 3 species that may be submitted for reconsideration by the "Lebanon Bird Record Committee" (LBRC) at LCNRS; and updated the data of 9 species of high significance from the past studies, of which, 2 species are upgraded from vagrants to winter visitors/passage migrants, one to passage migrant and one to winter visitor. Regarding the final phenological statuses of species, one is resident breeding, one is summer breeding, 3 are formerly bred, one extirpated (extinct) from Lebanon 31 are passage migrant/winter visitors, 25 passage migrants only, 2 winter visitors and 14 vagrant species.
\end{abstract}

Keywords: seabirds, coastal birds, migrating, wintering, breeding, status, phenology, threat, distribution.

\section{INTRODUCTION}

Unlike the terrestrial bird species, the seabirds and coastal birds have not received much attention from the bird surveyors in Lebanon. Out of the 54 bird observers that published scientific ornithological papers on Lebanon, only 10 have mentioned seabirds and coastal birds in their publications with most of published papers are for the author of this manuscript. They are: Stenhouse (1904), Cawkell (1944), Hollom (1959), Kumerloeve (1962), Tohmé \& Neuschwander (1974), Macfarlane (1978), Evans (1994), Ramadan-Jaradi and Ramadan-Jaradi (1997), Bara (1998), Busuttil \& Flumm (1998), Ramadan-Jaradi and Ramadan-Jaradi (1999, 2001, 2002), Ramadan-Jaradi et al. (2004), Ramadan-Jaradi et al. (2005), Ramadan-Jaradi (2006), Ramadan-Jaradi et al. (2008), Ramadan-Jaradi (2010, 2017a, 2017b, 2017c), and Ramadan-Jaradi \& Itani (2018). 
However, since the previous checklist of the birds of Lebanon (Ramadan-Jaradi et al., 2008), many significant changes in the status and distribution of sea and coastal birds have been recorded. Checklists are never permanent, but the one presented here now relates more closely to a more standardized taxonomic approach being adopted for the OSME (Ornithological Society of the Middle East) Region, through the developing OSME Regional List (ORL) of bird taxa. (OSME) Region List is available on www.osme.org/ORL. It is worth noting that the ORL follows the International Community of Ornithologists (IOC) World Bird List (hereinafter IOC, downloadable at http://www.worldbirdnames.org/) taxonomy and nomenclature in principle, but where some divergence better highlights a tax on, exceptions are made and rationale are given.

Our present checklist follows this ORL List but it will be limited to Marine and Coastal Birds only. It will be a subject for the Lebanon Birds Rarities Committee (LBRC) to discuss and debate, which is why we present a number of taxa as hypothetical at present, because acceptance standards have rightly become more stringent as the subtle ties of bird identification have become better understood and more widely disseminated. Of the 407 recorded taxa in Lebanon (Ramadan-Jaradi et al., in preparation), 8.6\% are seabirds, 9.83\% are coastal birds (waders) including 2 waterbird species (Little Egret and Grey Heron) for being frequently seen on the coast and the islets during their passage in spring and autumn and during the wintering season too. Consequently, this checklist deals with $18.43 \%$ of the country's avifauna. In addition, the present checklist will most probably serve as a baseline study that may assist identifying future impact on birds of offshore windfarms or future sea-based offshore platforms and drilling rigs for oil.

\section{What are seabirds and coastal birds?}

Seabirds spend most of their lives at sea. For this reason, they have developed a range of characteristics adapted to the marine environment (BirdLife International, 2018).

There exists no single definition of which groups, families and species are seabirds, and most definitions are in some way arbitrary. In the words of several seabird scientists, "The one common characteristic that all seabirds share is that they feed in saltwater; but, as seems to be true with any statement in biology, some do not. However, by convention all of the Sphenisciformes and Procellariiformes, all of the Pelecaniformes and Suliformes except the darters, and some of the Charadriiformes (the skuas, gulls, terns, auks and skimmers) are classified as seabirds (Tully et al., 2009). The phalaropes are usually included as well, since although they are waders, two of the three species are oceanic for nine months of the year, crossing the equator to feed pelagically (Steele, 2008).

Loons and grebes, which nest on lakes but winter at sea, are usually categorized as waterbirds, not seabirds (Steele, loc. Cit.). Although there are a number of sea ducks in the family Anatidae that are truly marine in the winter, by convention they are usually excluded from the seabird grouping. Many waders and shorebirds are also highly marine, living on the sea's edge (coast), but are also not treated as seabirds, even though, they are incorporated as coastal or shore birds in the present study. Accordingly, there are 35 seabird species in Lebanon, comprising, gulls, terns, shearwaters, petrels and skuas, and 
40 coastal or shore birds comprising, some herons, stints, turnstones, sandpiper, godwits, pratincoles, etc.

\section{Background}

The marine and coastal avifauna of Lebanon are severely degraded predominantly due to a lack of knowledge about their species diversity and subsequently lack of coordination and management amongst the various sectors responsible for the marine and coastal zone, combined with a lack of consolidated data and information on the marine and coastal avifauna and limited awareness of the value and need for appropriate management amongst stakeholders. As such the present checklist has been proposed to address all the marine and coastal bird species in Lebanon as a prior step towards highlighting elsewhere the so-called priority species within datasheets, especially when it is time to protect them from potential collision with future sea windfarms.

The Lebanese coastline extends $220 \mathrm{~km}$ from the border in the North to Naqoura in the South along the eastern Mediterranean. It is mainly a rocky shoreline with stretches of sand $(20 \%)$ and pebbles inhabited by a variety of common and endangered marine and coastal bird species (MoE, IUCN, UN Environment and GEF, 2018). The degradation of the coastline and the sea quality under the impact of chaotic urbanization increased the number of threatened bird species at the national level (Ramadan-Jaradi, pers. obs.). The degradation of the coastline is not the only reason behind the decline of marine and coastal birds as unfortunately, the dynamiting and the poisoning of fish with fish-poisoning products have an impact on human health and also repercussions threatening the life of sea birds that may feed on these poisoned fish (in July 2018, over 40 Yellow-legged Gulls were found dead or morbid on the beaches of Palm Islands Nature Reserve (RamadanJaradi, pers. obs.). Post-mortem proved that they were poisoned by fish poisoning products ingested by fish that are eaten on their turn by sea birds. On beaches, gull's eggs are stolen by fishermen to use them as aphrodisiac food. Gulls, waders and marine birds are killed by trash accidentally ingested; and in the sea the diving cormorants are caught by fishing nets. These destructive activities are predominantly due to the lack of law enforcement capacity and the current overlap and conflict among existing legislation and institutional mandates (Palm Islands Nature Reserve [PINR], 2018).

In view of the current situation of the Lebanese coastline and associated marine and coastal ecosystems and biodiversity, there is an intention to mainstream marine and coastal avifauna into national plans and coastal zone management plans, with particular focus on the impact of climate change on avian marine species. The present study provides an opportunity for the protection of key marine and coastal avian biodiversity to be included in coastal zone management plans as they are essential to the proper management of the marine ecosystem in Lebanon.

\section{METHODOLOGY}

The methodology used depends on the objectives of the present study that are to determine the seabird species, their phenological and conservation statuses, their frequency/abundance as well as their national distribution. Accordingly, we surveyed the study area, along the shore line and up to $7 \mathrm{~km}$ offshore, between early December 2016 
and early December 2018 with the point counts method during the breeding season (March-May) and linear transects during the remaining months of the year, often between 08:30 and 16:00 hr. The point counts method used was that described by Blondel et al. (1981) and successfully used by the author of this paper in his doctoral thesis in the desert of UAE (1984). The points are randomly selected within a stratified sampling process to provide representative samples of the study area (for more details on this methodology see Ramadan-Jaradi, 2017d).

It is worth to note that for each species of low occurrence, we added the old records from the past whether they are from the coastal area or from the inland wetlands. This was necessary to put the uncommon and rare species in a wider context.

\section{How to use the checklist}

Taxa are sequenced according to IOC order. For each taxon, its Common Name, Arabic Name, and Scientific Name are given. Global IUCN Threat Status (TS) is provided. This is an annotated checklist that provides a description of the distribution of each taxon.

\section{Threat Status (TS) index}

$\mathrm{CR}=$ Critically Endangered

$\mathrm{EN}=$ Endangered

$\mathrm{VU}=$ Vulnerable

NT $=$ Near Threatened

$\mathrm{LC}=$ Least Concern:

$L C=$ Grey boxes and italicized Threat Status categories indicate OSME estimated status

\section{Phenological Status}

The Phenological Status is also given with the following abbreviations:

A question mark indicates uncertain status.

Lower case abbreviations ( $e g \mathrm{r}, \mathrm{sb}, \mathrm{s}$, wv and $\mathrm{pm}$ ) indicate that the species is uncommon or rare at the relevant season.

$\mathrm{R} \quad$ Resident with definite breeding records

SB Breeding summer visitor

$\mathrm{S} \quad$ Non-breeding summer visitor

WV Winter visitor

PM Passage migrant

FB $\quad$ Formerly bred (no breeding records since 1987)

v Vagrant

e Extinct in Lebanon

I Introduced to Lebanon

** Extreme rarity sign given after the Common Name. 
Hereinafter, we divide the annotated list into 2 categories, one for the marine and pelagic (seabirds) species and one for the shore or coastal bird species that may have marine/freshwater life.

\section{Marine Avian Species (Table 1)}

Table 1. Annotated checklist of the marine bird species.

\begin{tabular}{|l|l|l|l|l|l|l|}
\hline & TS & English Name & Scientific Name & Arabic Name & $\begin{array}{l}\text { Phenologycal } \\
\text { Status }\end{array}$ & $\checkmark$ \\
\hline & \multicolumn{2}{|l|}{ PROCELLARIIFORMES } & & & & \\
\hline 1 & LC & European Storm Petrel & $\begin{array}{l}\text { Hydrobates } \\
\text { pelagicus }\end{array}$ & V & \\
\hline
\end{tabular}

Three records: singles off Ras Beirut on 18 September 1996 (Ramadan-Jaradi \& Ramadan-Jaradi, 1999), 10 April 1997 (Busuttil \& Flumm, 1998) and one at Naqoura, near southern border, on 21 December 2003 (GR-J in Ramadan-Jaradi et al., 2008).

\begin{tabular}{|l|l|l|l|l|l|l}
\hline 2 & VU & Leach's Storm Petrel & $\begin{array}{l}\text { Hydrobates } \\
\text { leucorhoa }\end{array}$ & طائر نو ليتش & ?wV \\
\hline
\end{tabular}

Four records suggest the species may be an overlooked rare winter visitor rather than a true vagrant: singles off Damour on 20 December 1995, and near Ramkine Island, on 12 October 1996 (Ramadan-Jaradi \& Ramadan-Jaradi, 1999); two off Ain el Mreissa in Beirut, on 22 December 2002, one off Khaldeh, on 3 February 2003 (Ramadan-Jaradi et al., 2004, 2008), one at Tripoli Harbour 29 March 2008 (Mike Orr, pers. Comm.), one on Palm Islands on 11 February 2017 and one at Cheikh Zennad sea on 10 February 2017 (Ramadan-Jaradi, 2017).

\begin{tabular}{|l|l|l|l|l|l|l|}
\hline 3 & LC & Scopoli's Shearwater & $\begin{array}{l}\text { Calonectris } \\
\text { [diomedea] } \\
\text { diomedea }\end{array}$ & PM, wv & ملاء كوري \\
\hline
\end{tabular}

Common on passage March-mid May and early August-late September and recorded irregularly in large flocks offshore and near Palm Islands in January-February. Seen in Batroun, Beirut, Naqoura, Palm Islands, Tripoli and Tyre Coast (Ramadan-Jaradi et al 2008, Ramadan-Jaradi 2017). First recorded by Van Dyck in 1873-1878 (Carruthers, 1910, Kumerloeve, 1962).

\begin{tabular}{l|l|l|l|l|l|}
\hline 4 & NT & Sooty Shearwater & Ardenna grisea & ج & V
\end{tabular}

One record: two north of Beirut on 16 March 1981 (Khairallah 1986).

\begin{tabular}{|l|l|l|l|l|l|}
\hline 5 & LC & Great Shearwater ** & Ardenna gravis & جلم ماء كبير & V
\end{tabular}

Three records: singles at Ras Beirut on 29 December 1974 and 1 January 1975 (Macfarlane, 1978) and three near Palm Islands on 5 January 2003 (Ramadan-Jaradi et al., 2004). Given the late dates during which this species was recorded, the LBRC may wish to assess its occurrence in Lebanon.

\begin{tabular}{|l|l|l|l|l|l|l}
\hline 6 & VU & $\begin{array}{l}\text { Mediterranean } \\
\text { Yelkouan Shearwater }\end{array}$ & Puffinus yelkouan & جلم ماء البحر المتوسط, wv \\
\hline
\end{tabular}

Common on passage, usually in small numbers from early August-early September (200 reported off Tripoli in late September) and March-April. Few winter records of singles or flocks (up to 55) often mixing with Common Black-headed Gull Larus ridibundus while resting on surface water during November-February (GR$\mathrm{J}$ in Ramadan-Jaradi et al., 2008; Ramadan-Jaradi, 2017). Observed offshore; Batroun, Beirut, Palm Islands, Tripoli and Naqoura. First recorded in 1877 by Van Dyck (Kumerloeve, 1962).

\begin{tabular}{|l|l|l|l|l|l|l|}
\hline & PHOENICOPTERIFORMES & & & \\
\hline 7 & LC & Greater Flamingo & $\begin{array}{l}\text { Phoenicopterus } \\
\text { roseus }\end{array}$ & pm, ?wv & \\
\hline
\end{tabular}


Status prior to 1999 unclear (Ramadan-Jaradi \& Ramadan-Jaradi, 1999). Recent records suggest that the species is a rare passage migrant and probably an equally scarce winter visitor, rather than a vagrant (RamadanJaradi et al., 2004, 2008). Further observations indicate all wintering attempts failed due to poacher's pressure. Recorded at Aammiq, Batroun, Beirut, Byblos, Cheikh Zennad, Enfeh, Khaldeh, Nahr Ibrahim, Palm Islands and Qleiaat. First recorded in 1881 by Van Dyck (Kumerloeve, 1962).

\begin{tabular}{|l|l|l|l|l|l|l|}
\hline & TS & English Name & Scientific Name & Arabic Name & $\begin{array}{l}\text { Phenologycal } \\
\text { Status }\end{array}$ & $\checkmark$ \\
\hline & PELECANIFORMES & & & & \\
\hline 8 & LC & Great White Pelican & $\begin{array}{l}\text { Pelecanus } \\
\text { onocrotalus }\end{array}$ & PM & \\
\hline
\end{tabular}

Common regular passage migrant at both seasons with flocks of up to 1,000 birds near coasts, at Aammiq and Qaraoun, and over mountains up to $1,800 \mathrm{~m}$ asl. Occurs mid-February-early June and early September-late November, principally on Palm Islands. First recorded by Tristram (1882).

\begin{tabular}{l|l|l|l|l|l|}
\hline 9 & LC & Pink-backed Pelican & Pelecanus rufescens & V & البجع الرمادي \\
\hline
\end{tabular}

Two records: one at Beirut on 25 March 1876 (Van Dyck in Kumerloeve (1962) and Benson (1970) and one dead bird [possibly taken in Batroun, in March 2003 (see Ramadan-Jaradi et al., 2004); given that this mainly African species is traded extensively, the LBRC may care to debate the latter's origin].

\begin{tabular}{l|l|l|l|r|l} 
pm & Dalmatian Pelican & Pelecanus crispus & البجع الدلماسي & pm
\end{tabular}

Scarce: small flocks principally in March-April and November, in the Beqaa Valley, off Tyre, Tripoli and on Palm Islands (Ramadan-Jaradi \& Ramadan-Jaradi, 2001). Largest flock encountered c45 on 3 April 1975 (Macfarlane, 1978). Semi-captive bird seen 10 June 2015 by GRJ, it was found by a fisherman in the Damour River Estuary April 2015, (Ramadan-Jaradi \& Itani, 2016). Observed in Damour, Palm Islands, Tripoli and Tyre. First recorded by Tristram (1882).

\begin{tabular}{|c|c|c|c|c|c|}
\hline & SUL & FORMES & & & \\
\hline 11 & $\mathrm{LC}$ & Northern Gannet & Morus bassanus & أطيش الشمال & v. ?wV \\
\hline
\end{tabular}

Scarce in winter, late November - late April, principally off the Batroun, Beirut, Enfeh, Naqoura, Palm Islands and Tripoli coasts. The largest flock recorded was of nine birds at Naqoura on 14 December 2003 (RamadanJaradi et al., 2005). First recorded 1894 by Van Dyck (Kumerloeve 1960, 1962).

\begin{tabular}{|l|l|l|l|l|l}
\hline 12 & LC & Pygmy Cormorant & $\begin{array}{l}\text { Microcarbo } \\
\text { pygmeus }\end{array}$ & w اب البحر القزمي & wv, pm, s \\
\hline
\end{tabular}

Occasional passage in November and March, and scarce winterer, December-February, principally off Naqoura in the south and Palm Islands in the north. A single adult bird lingered at Aammiq from 24 June to 14 July 2005 (seen on 17 dates) (Colin Conroy pers. Comm.). In the past, reported from inland at the Litani River (Tristram, 1864) and at Aammiq Swamp in November 1954 (Nevins, 1960).

\begin{tabular}{|l|l|l|l|l|l|}
\hline 13 & LC & $\begin{array}{l}\text { Continental Great } \\
\text { Cormorant }\end{array}$ & $\begin{array}{l}\text { Phalacrocorax } \\
\text { carbo) sinensis }\end{array}$ & WV, PM, s \\
\hline
\end{tabular}

Common along coasts and on Palm Islands, and to a lesser extent at Aammiq Swamp and Qaraoun Lake in October-early April. Occasionally oversummers (May-August), usually on Sanani and Ramkine islands (Ramadan-Jaradi \& Ramadan-Jaradi 1999). Occurred at Aammiq, Al Mansoura, Al Mansouri, Al Quaser, Anfeh, Beirut, Cheikh Zennad, Hermel, Koura, Mina, Naqoura, Palm Islands, Qaraoun, Saida, Tripoli and Tyre Coast. First recorded at Beirut in 1894 by Van Dyck (Kumerloeve, 1962).

\begin{tabular}{|l|l|l|l|l|l|l|}
\hline & CHARADRIIFORMES & & & \\
\hline 14 & LC & Black-legged Kittiwake & Rissa tridactyla & v & \\
\hline
\end{tabular}

Recorded from Ras Beirut: records in January (three), November (five) and December (eight) in 1974-1975 (Macfarlane 1978), at Palm Islands Reserve on 15 February 1998 (Ramadan-Jaradi \& Ramadan-Jaradi, 1999) and at Tripoli February and March 2009 where up to 7 birds were seen on five occasions (Mike Orr and Karen Wade, pers. Comm.). 


\begin{tabular}{|l|l|l|l|l|l|l|}
\hline & TS & English Name & Scientific Name & Arabic Name & $\begin{array}{l}\text { Phenologycal } \\
\text { Status }\end{array}$ & $\checkmark$ \\
\hline 15 & LC & Slender-billed Gull & $\begin{array}{l}\text { Chroicocephhalus } \\
\text { genei }\end{array}$ & pm, wv & \\
\hline
\end{tabular}

Irregular spring passage migrant and winter visitor. Benson (1970) and Ramadan-Jaradi\& Ramadan-Jaradi (1999) list few records. Five offshore Tyre Coast on 11 April 2005 (GR-J) and four flew north past Tripoli on 3 Mar 2006 (Richard Prior pers. Comm.). In recent years, records and examination of digital photos showed the species is scarce on passage and uncommon in winter. Recorded in Cheikh Zennad, El-Kalb River, Mina, Tripoli and Tyre Coast. First recorded by Tristram (1864).

\begin{tabular}{|l|l|l|l|r|l|}
\hline 16 & LC & $\begin{array}{l}\text { Common Black-headed } \\
\text { Gull }\end{array}$ & $\begin{array}{l}\text { Chroicocephalus } \\
\text { ridibundus }\end{array}$ & نورس أسود الرأس, WV \\
\hline
\end{tabular}

Abundant passage migrant and winter visitor from August-late April with peaks in November-December when flocks of several 100s are present. Recorded on islands, coasts, fishponds, estuaries and irregularly at inland waters where usually less than ten at one site. First recorded by Van Dyck in 1873-1878 (Kumerloeve, 1960, 1962).

\begin{tabular}{|l|l|l|l|l|l|l|}
\hline 17 & LC & Little Gull & $\begin{array}{l}\text { Hydrocoloeus } \\
\text { minutus }\end{array}$ & pm, WV & صورس صغير \\
\hline
\end{tabular}

Uncommon passage migrant September-November and March-mid-May with peaks up to 65 in April (GR-J), principally at Cheikh Zennad; and common winter visitor December-February, with peaks up to 100 in January (GR-J), on islands, coasts, estuaries and to a lesser extent at inland waters (Qaraoun and Yammouneh). Sighted at Aammiq, Beirut, Cheikh Zennad, Damour, Khaldeh, Palm Islands, Qaraoun, Qleiaat, Saida and Yammouneh. First recorded by Van Dyck in 1873-1878 (Kumerloeve 1960, 1962).

\begin{tabular}{|l|l|l|l|l|l|}
\hline 18 & LC & Audouin's Gull & $\begin{array}{l}\text { Ichthyaetus } \\
\text { audouinii }\end{array}$ & FB, pm \\
\hline
\end{tabular}

Bred on Palm island in 1895 (Stenhouse, 1904); 18 there but apparently not breeding on 3 April 1973 (Tohmé \& Neuschwander, 1974); seven more records at the same place: ten on 23 August 1997 (Ramadan-Jaradi \& Ramadan-Jaradi, 1999), one on 1, 4 and 25 April 1998 and one on 6 July 2000 (Ramadan-Jaradi \& RamadanJaradi, 2001); three on 4 April 2002 and four on 11 August 2004 (GR-J). Elsewhere: three off Beirut on 3 October 1958 (Flach, 1959), five at Cheikh Zennad on 25 August 1996 (Bara, 1998), six there on 5 April 2002 and 14 on 1 September 2003 (Ramadan-Jaradi, 2003). These records above suggest that the Audouin's Gull is a rare passage migrant rather than vagrant.

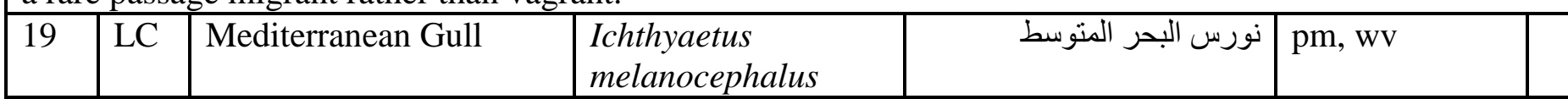

Scarce and irregular passage migrant and winter visitor. Fairly common offshore in autumn and winter (Benson, 1970); recorded on seven dates in January (Nevins, 1960, Macfarlane, 1978), seven in February and five in March (Macfarlane, 1978); two in December (Macfarlane, 1978; Balmer \& Betton, 2006) and one record of two on 10 April 1997 (Busuttil \& Flumm, 1998). One Tripoli 8 February 2008 (Mike Orr pers. Comm.), and one Tyre Coast 3 April 2017 (GR-J). First recorded by Schrader (1892).

\begin{tabular}{|l|l|l|l|l|l|l|}
\hline 20 & LC & $\begin{array}{l}\text { Great Black-headed } \\
\text { Gull }\end{array}$ & $\begin{array}{l}\text { Ichthyaetus } \\
\text { ichthyaetus }\end{array}$ & pm, wv & (أسود الر أس كبيز \\
\hline
\end{tabular}

Recently several records during October-April indicate that the Great Black-headed Gull is a scarce to uncommon passage migrant and winter visitor. Previously, it was considered vagrant with only five records (Ramadan-Jaradi \& Ramadan-Jaradi, 1999). Reported from Aammiq, Bellan Islet, Cheikh Zennad, Palm Islands, Qaraoun Lake, Ras Beirut, Ras el Chekaa, Saida, Tel el Akhdar, Tripoli and Tyre. First recorded in 1975 (Macfarlane, 1978). 


\begin{tabular}{|l|l|l|l|l|l|l|}
\hline & TS & English Name & Scientific Name & Arabic Name & $\begin{array}{l}\text { Phenologycal } \\
\text { Status }\end{array}$ & $\checkmark$ \\
\hline 21 & LC & Sooty Gull & $\begin{array}{l}\text { Ichthyaetus } \\
\text { hemprichii }\end{array}$ & v & \\
\hline
\end{tabular}

One record: one near Tyre on 22 October 1958 (Flach 1959).

\begin{tabular}{l|l|l|l|r|l}
\hline 22 & LC & Common Gull & Larus canus & نورس رمادي إعتيادي & WV, pm, s
\end{tabular}

Scarce passage migrant in March and early November-mid-December, and widespread and common winter visitor in December-late February, with small numbers oversummering in June-July off Tripoli. Sighted at Beirut, Palm Islands, Tripoli, Tyre and Naqoura. First recorded by Van Dyck in 1873-1878 (Kumerloeve 1960, 1962).

\begin{tabular}{|l|l|l|l|r|l}
\hline 23 & LC & $\begin{array}{l}\text { Great Black-backed } \\
\text { Gull ** }\end{array}$ & Larus marinus & pm, wv \\
\hline
\end{tabular}

Extremely rare passage migrant and winter visitor. The first part of Benson's (1970) statement that "a few are seen offshore here in most seasons, chiefly immature birds in autumn and winter" appears unlikely given the pattern of records elsewhere in this part of the Middle East. Singles off Antelias on 7 April and 12 December 1995, off Beirut on 15 March 1996, on Palm Islands on 5 May 1996 (Ramadan-Jaradi \& Ramadan-Jaradi, 1999) and 14 at Cheikh Zennad on 22 September 2002 (Ramadan-Jaradi \& Waterbury, 2002). First recorded by Schrader (1892).

\begin{tabular}{|l|l|l|l|r|l|}
\hline 24 & LC & Caspian Gull & Larus cachinnans & wv, ?pm \\
\hline
\end{tabular}

One recorded at el Mina/Tripoli on 9 November 2004 (Nidal Issa pers. Comm.), [a few adults and immature at Cheikh Zennad on 30 January 1998 were thought to be this taxon (TB)], and one adult observed and photographed at Palm Islands on 25 January 2008, following an intensive search since 13 January. The latter showed more white on the black wing tip than the Yellow-legged Gull L. michahellis, paler grey upperparts, more flattened front, pinkish legs and black eyes (GR-J). Prior to the elevation of the Caspian Gull to the rank of species, most birders were not applying the ID criteria for the two forms. Nevertheless, few past photographs showed Caspian Gull characters clearly enough. Future observations will doubtless confirm the status of this species.

\section{\begin{tabular}{l|l|l|l|l|l|}
\hline 25 & LC & Yellow-legged Gull & Larus michahellis & R, PM, WV, S \\
\hline
\end{tabular}}

Resident breeder (eggs mid-April, except for 2007 when first chicks hatched on 12 April) in fair numbers on Palm Islands (see Ramadan-Jaradi \& Ramadan-Jaradi (1997, 1999, and 2001). Fairly common passage migrant in March-mid-May and mid-August-early November; a relatively common winter visitor in mid-Novemberlate February, and Fairly common non-breeding summer visitor in May-July. Occasional at inland wetlands. First recorded by Tristram (1864) and first breeding record was on Palm Islands in 1956 (Hollom 1959). Recently breeding was reconfirmed (for over 36 years) at Palm Islands in 1996 (Ramadan-Jaradi \& RamadanJaradi, 1997, 1999, 2001).

\begin{tabular}{|l|l|l|l|r|l|}
\hline 26 & LC & Armenian Gull & Larus armenicus & wv, pm \\
\hline
\end{tabular}

Four records: four at Tyre on 11 October 1996 (Ramadan-Jaradi \& Ramadan-Jaradi 1999), eight at Cheikh Zennad on 22 March 1997 with one there on 5 April 1997 (Bara 1998) and [significant numbers were reported from Qaraoun Lake on 25 January 2001 - see Balmer \& Betton (2001)]. The species was reported on nine occasions at Tripoli during January, February and March 2008, 2009, 2010 with a maximum of 11 individuals at any one time (Mike Orr and Karen Wade pers. Comm.) and 15 occasions on rocky islets between Mina and Palm Islands during the winters 2016, 2017 and 2018 (all photographed by GR-J). Elsewhere, two or more individuals were seen at Daoura 31 March 2017 (JH). Previously considered a vagrant but the more recent records suggest the species is a scarce migrant and scarce winter visitor.

\begin{tabular}{|l|l|l|l|l|l|}
\hline 27 & LC & Baltic Gull & Larus fuscus fuscus & نورس البلطيق & PM, WV, s \\
\hline
\end{tabular}

Abundant passage migrant in early March-late May and mid-August-early November, and common winter visitor in mid-November-mid-March along coasts and offshore. (Ramadan-Jaradi \& Ramadan-Jaradi, 1999). 
Vagrant at Aammiq wetland (Beale \& Sprenger, 2001). Very small numbers regularly over summer in coastal areas, particularly at Palm Islands. Reported from Aammiq, Beirut, Bwar, Byblos, Chekka, Cheikh Zennad, Dbaye, Damour, Daoura, Dbaye, Jiyeh, Jounieh, Nahr el Kalb mouth, Nahr Ibrahim mouth, Ouzai, Palm Islands, Sour and Tripoli. First recorded in 1824 (Hemprich \& Ehrenberg, 1833).

\begin{tabular}{|l|l|l|l|r|l|l|}
\hline & TS & English Name & Scientific Name & Arabic Name & $\begin{array}{l}\text { Phenologycal } \\
\text { Status }\end{array}$ & $\checkmark$ \\
\hline 28 & LC & Heuglin's Gull & $\begin{array}{l}\text { Larus (fuscus/ } \\
\text { heuglini) heuglini }\end{array}$ & V & & \\
\hline
\end{tabular}

Two records: two at Tripoli on 2 April 2001 (Marc Almecija pers comm) and one at the mouth of Beirut River on 6 January 2004 (Bara, 1998). Being insufficiently documented so far by the observers, this hard-to-identify species will necessarily be another candidate for the LBRC].

\begin{tabular}{|l|l|l|l|l|l}
\hline 29 & LC & Gull-billed Tern & $\begin{array}{l}\text { Gelochelidon } \\
\text { nilotica }\end{array}$ & pm \\
\hline
\end{tabular}

Tristram's late 19th century report that the species was found on sand-spits and lagoons near Tyre and Beirut cannot be confirmed (see Kumerloeve (1962). With only two records at Qaraoun and Cheikh Zennad in 199697 (Bara 1998), the Gull-billed Tern was considered a vagrant (Ramadan-Jaradi \&Ramadan-Jaradi (1999). Recently, four additional records suggest that the species is a rare passage migrant rather than vagrant: three among tern flocks at Mina/ Tripoli, on 14 January 2000, 11 at Cheikh Zennad on 31 March, with 13 there on 2 April 2001 (Marc Almecija pers. Comm.), and two at Lake Qaraoun on 4 August 2005 (Colin Conroy pers. Comm.). One additional record at Sheikh Zennad by Bassel Abi Jummaa on 18, July, 2011.

\begin{tabular}{|l|l|l|l|r|r|}
\hline 30 & LC & Lesser Crested Tern & $\begin{array}{l}\text { Thalasseus } \\
\text { bengalensis }\end{array}$ & FB, e \\
\hline خغاف بحر (خرشنة) منوج
\end{tabular}

Bred on Palm island in 1895 (Stenhouse 1904). No subsequent records (Ramadan-Jaradi \& Ramadan-Jaradi 1999).

\begin{tabular}{|l|l|l|l|r|l|}
\hline 31 & LC & Sandwich Tern & $\begin{array}{l}\text { Thalasseus } \\
\text { sandvicensis }\end{array}$ & pm, WV \\
\hline
\end{tabular}

Thalasseus sandvicensis Sandwich Tern pm, WV: Extremely rare passage migrant and winter visitor in early August-mid-April to coasts (Ramadan-Jaradi \& Ramadan-Jaradi, 1999) and Palm Islands (Ramadan-Jaradi \& Ramadan-Jaradi, 2001). Records since 2008 till today showed that the species is much commoner in winter and scarce on passage. Sighted at Beirut, Byblos, Cheikh Zennad, Damour, Dbayyeh and Palm Islands, Tripoli and Tyre Coast. First recorded in 1878 by Van Dyck (Kumerloeve, 1962).

\begin{tabular}{l|l|l|l|l|l|}
32 & LC & Little Tern & Sternula albifrons & خطاف بحر (خرشنة) صغنير & FB, pm
\end{tabular}

Bred on Palm Islands at the end of the 19th century (Stenhouse, 1904) but no subsequent records until 11 at Cheikh Zennad on 14 June 1996, three there on 8 September 1996 and eight on 16 May 1997 (TB), one at Sanani island on 4 April 1998 (Ramadan-Jaradi \& Ramadan-Jaradi, 1999) and two at Qaraoun Lake on 27 September 2003 (GR-J). All these records suggest that the Little Tern is a very rare passage migrant rather than vagrant. First recorded in 1877 by Van Dyck (Kumerloeve, 1962).

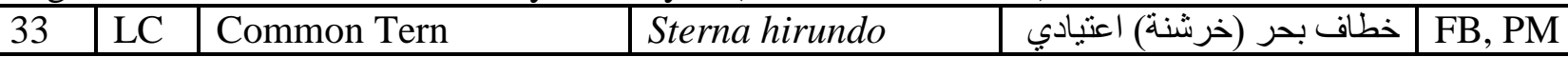

Formerly bred on Palm Islands (Stenhouse, 1904) but considered a vagrant by Cramp (1985). Presently, common passage migrant in early April-late May and early August-early October, on coasts and islands; only one early record - 21 February 1998 (see Ramadan-Jaradi \& Ramadan-Jaradi, 1999). Observed at Abdeh, Beirut, Cheikh Zennad, Dbayyeh, Jounieh, Khaldeh, Palm Islands, Tripoli and Naqoura. First recorded by Schrader (1892).

\begin{tabular}{|l|l|l|l|r|l}
\hline 34 & LC & Pomarine Skua & $\begin{array}{l}\text { Stercorarius } \\
\text { pomarinus }\end{array}$ & pm, wV \\
\hline
\end{tabular}

Twenty records: twelve records at Ras Beirut in February, August-September and December 1974-1976 (Macfarlane, 1978), one or two off Beirut on 10 April (Kirwan, 1997), six there during 8-11 April 1997 
(Busuttil \& Flumm, 1998), one single at El Mina/Tripoli on 14 January 2000 (Marc Almecija pers. Comm.), one off Palm Islands on 20 February 2001 and one off Beirut on 17 April 2001 (Ramadan-Jaradi \& RamadanJaradi 2002); and one single over Palm Islands on 11 May 2001 (Ramadan-Jaradi \& Sandwith unpub.). All these records show that the species is a scarce passage migrant and rare winter visitor rather than a vagrant (see Ramadan-Jaradi \& Ramadan-Jaradi, 1999). First recorded in 1974 (Macfarlane, 1978).

\begin{tabular}{l|l|l|l|l|l}
\hline 35 & LC & Arctic Skua & $\begin{array}{l}\text { Stercorarius } \\
\text { parasiticus }\end{array}$ & pm, wV \\
\hline
\end{tabular}

\section{Coastal Avian Species}

The coastal wetlands, rocky shores, sandy beaches, shallow waters and mudflats of Lebanon support a wide variety of shorebirds. Shorebirds include plovers, sandpipers, oystercatchers, and turnstones. In some regions, shorebirds are considered wading birds. The following are the coastal birds of Lebanon: (Table 2)

Table 2. Annotated checklist of the coastal bird species.

\begin{tabular}{|l|l|l|l|l|l|l|}
\hline & TS & English Name & Scientific Name & Arabic Name & $\begin{array}{l}\text { Phenologycal } \\
\text { Status }\end{array}$ \\
\hline & & PELECANIFORMES & & & & \\
\hline 1 & LC & Grey Heron & Ardea cinerea & pm, wv & \\
\hline
\end{tabular}

Common on passage on islands, coasts, estuaries and at inland waters, most frequent at Palm Islands, Cheikh Zennad, Aammiq and Tanayel, in late February-early June and beginning August-mid-November. Recorded wintering in small (20 ind.) but regular numbers on Palm Islands (Ramadan-Jaradi \& Ramadan-Jaradi, 1999; 2008; and till present) and at Aammiq, where also non-breeding singles were occasionally observed in June (Beale \& Sprenger 2001). Reported from Aichyeh, Aammiq, Ain Zebdeh, Al Mansouri, Anjar, Azour, Beirut, Bishmezzine, Chekka, Cheikh Zennad, Mina, Nahr Ibrahim, Ouzai, Qaraoun, Palm Islands, Saida, Tanayel and Tripoli. First recorded in 1881 by Van Dyck (Kumerloeve, 1962).

\begin{tabular}{|l|l|l|l|r|l|l|}
\hline 2 & LC & Little Egret & Egretta garzetta & البلثون الأبيض الصغير sb,PM, wv, S
\end{tabular}

Common and regular passage on coasts, estuaries, cultivated fields in lower montane areas and at inland waters, in small flocks (up to 30), from March-early June (most April-May), and August-late October. Maximum count 91 occurred at Aammiq on 31 August 2007 (Colin Conroy pers. Comm.). Scarce to uncommon winterer on coast. Very recently (7 May 2020), it was found breeding, beside Night Heron, Squacco Heron and Cattle Egret, in conifer trees on an inland islet surrounded by a pond at Mansoura, at the West-Beqaa area (Ramadan-Jaradi, G., Fouad Itani, and Maher Osta, pers. obs.). Up to 50 were recorded on daily basis between 10 and 18 July 2004 at Qaraoun Lake (Ramadan-Jaradi et al., 2004). Reported from Aammiq, Al Mansoura, Al Mansouri, Beirut, Bwar, Cheik Zennad, Chekka, Damour, Daoura, Dbayeh, Enfe, Hosh al Harime, Zahleh, Jbeil, Jounieh, Khaldeh, Litani, Nahr el Kalb, Ouzai, Nahr Ibrahim, Palm Islands, Qaraoun, Tanayel, Tripoli and Tyre. First recorded in 1954 (West, 1954). 


\begin{tabular}{|l|l|l|l|l|l|l|}
\hline & TS & English Name & Scientific Name & Arabic Name & $\begin{array}{l}\text { Phenologycal } \\
\text { Status }\end{array}$ & \\
\hline & \multicolumn{2}{|l|}{ CHARADRIIFORMES } & & & & pm, wv, s \\
\hline 3 & NT $\quad$ Eurasian Oystercatcher & $\begin{array}{l}\text { Haematopus } \\
\text { ostralegus }\end{array}$ & آلحار & \\
\hline
\end{tabular}

With only four records between 1955 and 1998, the Oystercatcher was considered vagrant in Lebanon (Ramadan-Jaradi \& Ramadan-Jaradi, 1999). Recent observations on Palm Islands Nature Reserve (RamadanJaradi, 2003) cover in 2002 one on 23 April and, two on 28 September and in 2003, one on 7 April and five on 11 May. Elsewhere, a putrefied corpse was found at Qaraoun Lake on 24 May 2004 (GR-J). Outside the range of the passage dates, one at Beirut on 9 July 2006 (Colin Conroy pers. Comm.). A single bird was seen regularly at Tripoli 8 April 2008, 25 November 2008, 4 December 2008, 27 January 2009 and 29 February 2009 (Mike Orr and Karen Wade, pers. Comm.). Further individuals were seen by FI at Ouzai 22 July 2015 and Tripoli 29 December 2017. These records suggest that the Oystercatcher is a regular but scarce passage migrant, the September record being the first for autumn (Ramadan-Jaradi et al., 2005 and 2008). Reported from Beirut, Cheikh Zennad, Khaldeh and Palm Islands. First recorded in 1955 (Nevins, 1960).

\begin{tabular}{|l|l|l|l|l|l|}
\hline 4 & LC & Black-winged Stilt & $\begin{array}{l}\text { Himantopus } \\
\text { himantopus }\end{array}$ & PM \\
\hline
\end{tabular}

Common passage migrant in early March-mid-May and mid-June-late October on islands (most on Palm Islands), coasts (principally at Cheikh Zennad and to a lesser extent Mina) and inland waters (most at Aammiq and Qaraoun). First recorded in 1877 by Van Dyck (Kumerloeve, 1962).

\begin{tabular}{|l|l|l|l|l|l|l|}
\hline 5 & LC & Pied Avocet & $\begin{array}{l}\text { Recurvirostra } \\
\text { avosetta }\end{array}$ & النكات & pm, wV & \\
\hline
\end{tabular}

Scarce passage migrant in ealy-March-mid-May and end July-late October on coasts and islands. The occurrence of 2 at Cheikh Zennad on 18 January 2002 and one there on 20 December 2006 (GR-J) indicate that the species is also a rare winter visitor. Sighted at Beirut, Beirut River, Borquael, Cheikh Zennad, Palm Islands, Qaraoun, Rachaya and Tanayel. First recorded by Schrader (1892).

\begin{tabular}{l|l|l|l|l|l|}
\hline 6 & LC & Eurasian Golden Plover & Pluvialis apricaria & pm, wv
\end{tabular}

Scarce passage migrant in March-April and uncommon in October-mid-November, mostly on coasts and in the Beqaa; extremely rare elsewhere. Few overwinter (late November-late March) in south Beqaa, Aammiq, Cheikh Zennad, Hermel and Ras Baalbeck. The largest number recorded is of c300 individuals flying very high overhead at Khaldeh (Costa Brava) on 19 January 2017 photographed by GR-J (identified by Richard Porter). First recorded by Tohmé \& Neuschwander (1974).

\begin{tabular}{|l|l|l|l|r|l|}
\hline 7 & LC & Pacific Golden Plover & Pluvialis fulva & vقاط ذهبي باسيفيكي & V \\
\hline
\end{tabular}

One record: one at Cheikh Zennad on 12 October 1996 is briefly described (Bara 1998).

\begin{tabular}{l|l|l|l|r|l}
\hline 8 & LC & Grey Plover & Pluvialis squatarola & pm, wV \\
\hline
\end{tabular}

Scarce passage migrant and winter visitor to coasts and islands in mid-August-late May. Recorded in AlMansouri, Beirut, Cheikh Zennad, Khaldeh, Mina, Palm Islands, Tripoli and Tyre Coat. First recorded by Tristram (1864).

\begin{tabular}{|l|l|l|l|r|l|l|}
\hline 9 & LC & $\begin{array}{l}\text { Common Ringed } \\
\text { Plover }\end{array}$ & Charadrius hiaticula & PM, wV, s & مطقاط (زقز اق) مطوق \\
\hline
\end{tabular}

Relatively common passage migrant in late March-early June and mid-August-late October on coasts, islands, fishponds and inland waters. Few overwinter in November-March on coasts and islands. Very small numbers of non-breeders oversummer from June-July at Tyre Coast, Cheikh Zennad and Palm Islands. Recorded at Aammiq, Beirut, Cheikh Zennad, Chwaifat, Joub Jannine, Khaldeh, Litani River, Palm Islands, Naqoura, Qaraoun and Tyre. First recorded in 1875 by Van Dyck (Kumerloeve, 1962).

\begin{tabular}{|l|l|l|l|l|l|l|}
\hline & TS & English Name & Scientific Name & Arabic Name & $\begin{array}{l}\text { Phenologycal } \\
\text { Status }\end{array}$ & \\
\hline
\end{tabular}




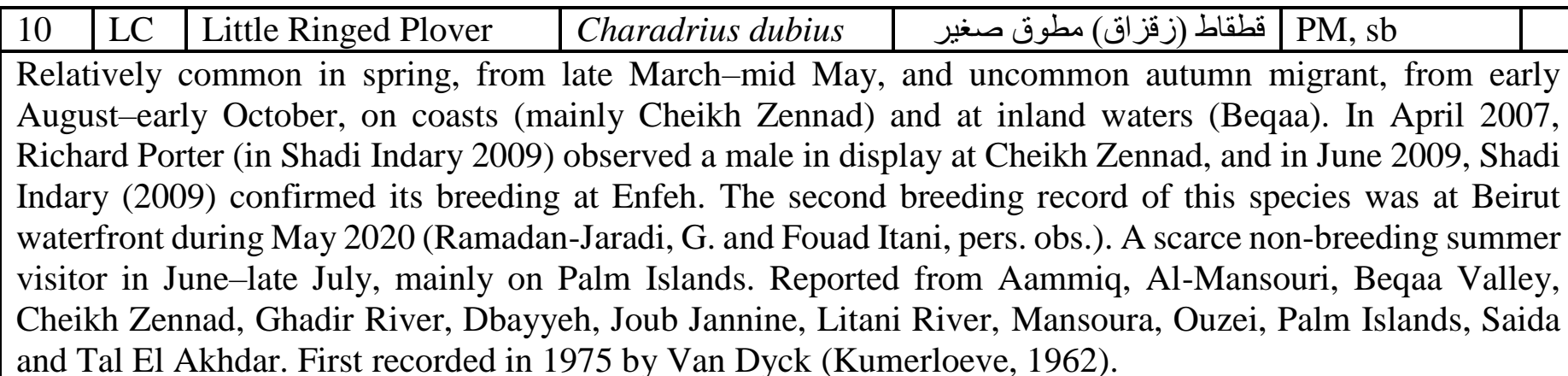

\begin{tabular}{l|l|l|l|l|}
\hline 11 & LC & Eurasian Dotterel & Charadrius & أغبر
\end{tabular}

\begin{tabular}{l|l|l|l|l}
\hline 11 & LC & Eurasian Dotterel & $\begin{array}{l}\text { Charadrius } \\
\text { morinellus }\end{array}$ \\
\hline
\end{tabular}

إطقاط (زقز ق) أغبر

Scarce in late September-November and only one spring record, of three at Tyre on 17 March 1995 (Ramadan-Jaradi \& Ramadan-Jaradi, 1999). Most records from coasts and the Beqaa Valley. Very small numbers occasionally winter in January-February at Qaraoun lake and the Litani River. Sighted at Al Qaser, Baalbek, Beirut, Beqaa Valley, Cheikh Zennad, Damour, Hermel, Litani River, Qaa, Qaraoun, Ras Baalbek and Tyre. First recorded by Van Dyck in 1873-1878 (Kumerloeve 1960, 1962).

\begin{tabular}{|l|l|l|l|l|l|}
\hline 12 & LC & Kentish Plover & $\begin{array}{l}\text { Anarhynchus } \\
\text { alexandrinus }\end{array}$ & pm, s \\
\hline
\end{tabular}

Rare to scarce passage migrant from early February-late May and early August-late December on coasts, estuaries and inland waters. Few non-breeders occasionally in June-July, mainly on coasts, Aammiq and Qaraoun Lake. Sighted at Aammiq, Al-Mansouri, Cheikh Zennad, Damour, Jiyeh, Khaldeh, Ouzei, Qaraoun, Palm Islands, Saida and Tyre. First recorded in 1904 (Carruthers, 1910).

\begin{tabular}{|l|l|l|l|l|l|}
\hline 13 & LC & Greater Sand Plover & $\begin{array}{l}\text { Anarhynchus } \\
\text { leschenaultii }\end{array}$ & pm, wv \\
\hline
\end{tabular}

Rare passage migrant from March-late April and occasional late July-September on coasts, fishponds and on Palm Islands. Two individuals recorded and photographed by FI and Maher Rouhana on the coast of Tripoli on 29 December 2017 suggest a very rare winter visitor. Reported from Aammiq, Al-Mansouri, Beirut, Byblos, Cheikh Zennad, Damour, Jiyeh, Khaldeh, Tripoli, Palm Islands, Tyre Coast and Naqoura. First recorded in 1877 by Van Dyck (Kumerloeve, 1962).

\begin{tabular}{|l|l|l|l|l|l|}
\hline 14 & LC & Caspian Plover & $\begin{array}{l}\text { Anarhynchus } \\
\text { asiaticus }\end{array}$ & v \\
\hline
\end{tabular}

Four records: one at Beirut on 21 March 1904 (Carruthers, 1910), one at the mouth of the Damour River on 26 April 1975 (Macfarlane, 1978), one at Cheikh Zennad, on 11 April 2002 (Ramadan-Jaradi et al., 2004), and one there on 22 September 2002 (Ramadan-Jaradi \& Waterbury, 2002).

\begin{tabular}{|l|l|l|l|l|l|l|}
\hline 15 & LC & Eurasian Whimbrel & Numenius phaeopus & sروان الماء الصغير & pm \\
\hline
\end{tabular}

Rare passage migrant in April and early August-mid-October on coasts and islands. Recorded at Beirut, Batroun, Cheikh Zennad, Nahr el Kalb, Naqoura, Ouzaii, Palm Islands, Sarafand, Tripoli and Tyre. First recorded in 1956 (Hollom, 1959).

\begin{tabular}{l|l|l|l|l|l}
\hline 16 & NT & Eurasian Curlew & Numenius arquata & كروان الماء & v, ?pm
\end{tabular}

Five records: one at Cheikh Zennad on 21 April 1996 and two there on 30 April 1996 (Bara 1998); three at Damour on 4 September 1996 (Ramadan-Jaradi \& Ramadan-Jaradi, 1999), one at Cheikh Zennad on 21 August 2005 (Colin Conroy pers. Comm.) and [one at Naqoura on 10 October 2006 (Ramadan Jaradi et al., 2008).

\begin{tabular}{|l|l|l|l|c|l|l|}
\hline & TS & English Name & Scientific Name & Arabic Name & $\begin{array}{l}\text { Phenologycal } \\
\text { Status }\end{array}$ & \\
\hline 17 & NT & Bar-tailed Godwit & Limosa lapponica & v & \\
\hline
\end{tabular}


Only four records: one at Cheikh Zennad on 12 May 1996 (Bara, 1998), one at Aammiq on 5 May 2000 (Ramadan-Jaradi, 2003), one there on 15 September 2000 (Beale \& Sprenger, 2001), and one at Tyre Coast on 14 October 2004 (Ramadan-Jaradi et al., 2005).

\begin{tabular}{l|l|l|l|r|l}
18 & NT & Black-tailed Godwit & Limosa limosa & pm
\end{tabular}

Scarce passage migrant during March-April and August-November. Four records at Aammiq: two on 17 March 1975 (Macfarlane 1978), one on 20 March 1997 (Busuttil \& Flumm, 1998), [one on 15 September 2000 (Kirwan, 2001)], and two on 11 October 2001 (Ramadan-Jaradi, 2003). Six records at Cheikh Zennad in April, August-September and November with a maximum of five on 5 April 1997 (Bara 1998). One at Cheikh Zennad on 14 April 2000 (Ramadan-Jaradi, 2003), one at Tel el Akhdar on 27 April 2005 (François Tron pers. Comm.), and one there on 16 April 2006 (Colin Conroy pers. Comm.). First recorded at Aammiq in 1975 (Macfarlane, 1978).

\begin{tabular}{l|l|l|l|l|l|}
\hline 19 & LC & Ruddy Turnstone & Arenaria interpres & pm
\end{tabular}

Scarce but regular passage migrant, mid-February-May and August-October, along the coast and at inland waters. Scarce winter visitor. Most at Cheikh Zennad, Palm Islands, Tyre Coast, Tripoli and Qaraoun Lake. Only one record from Aammiq on 2 May 2001 (GR-J). First recorded by Tohmé \& Neuschwander (1974).

\begin{tabular}{|l|l|l|l|r|l}
\hline 20 & LC & Sanderling & Calidris alba & المدروان & pm
\end{tabular}

Five records: one at Beirut in late spring 1876 (Van Dyck in Kumerloeve (1962), four at Cheikh Zennad on 15 September 1996 and eight there on 29 September 1996 (Bara, 1998), three at Cheikh Zennad on 22 September 2002, and six at Tyre Coast Nature Reserve on 6 October 2004 (Ramadan-Jaradi et al., 2005).

\begin{tabular}{|l|l|l|l|r|l|}
\hline 21 & LC & Little Stint & Calidris minuta & ديجة صغيرة
\end{tabular}

Common passage migrant in flocks of up to several 100s in early March-late May and early August-late October on coasts, islands, and wetlands throughout the country. Sighted at Aammiq, Beirut, Bwar, Cheikh Zennad, Ghadir River mouth, Joub Jannine, Khaldeh, Litani River, Naqoura, Palm Islands, Qaraoun and Tyre Coast. First recorded in 1882 by Van Dyck (Kumerloeve, 1962).

\begin{tabular}{l|l|l|l|l|l|l|l}
\hline 22 & LC & Dunlin & Calidris alpina & دريجة & PM, WV
\end{tabular}

Common passage migrant in August-mid-November and to a lesser extent April-May on coasts, islands and inland wetlands. Regularly recorded in December-February on Palm Islands and occasionally or locally in smaller numbers elsewhere. Reported from Aammiq, Beirut, Cheikh Zennad, Chwaifat, Enfeh, Khaldeh, Naqoura, Palm Islands, Qaraoun, Tanayel and Tyre Coast. First recorded in 1875 by Van Dyck (Kumerloeve, 1962).

\begin{tabular}{|l|l|l|l|l|l|}
\hline 23 & NT & Curlew Sandpiper & Calidris ferruginea & طيطوي مقوس المنقار pm, s \\
\hline
\end{tabular}

Scarce but regular passage migrant in late April-May and August-October on coasts and wetlands throughout Lebanon. Very small numbers oversummer in June-July on Palm Islands. Perhaps more common than observations suggest (Ramadan-Jaradi \& Ramadan-Jaradi, 1999). Sighted at Aammiq, Beirut, Cheikh Zennad, Qaraoun Lake and Palm Islands. First recorded by Ramadan-Jaradi \& Ramadan-Jaradi (1999).

\begin{tabular}{l|l|l|l|l|l|}
\hline 24 & LC & Temminck's Stint & Calidris temminckii & دريجة تمناك & pm
\end{tabular}

Scarce but regular passage migrant in late April-late May and mid-August-late October, mainly in Beqaa and to a lesser extent on coast, fishponds and estuaries. Reported from Aammiq, Beqaa Valley, Cheikh Zennad, Damour, Ghadir River mouth, Joub Jannine, Litani River, Naqoura, Palm Islands and Qaraoun Lake. First recorded by West (1954).

\begin{tabular}{|l|l|l|l|l|l|l|}
\hline 25 & NT & Red Knot & Calidris canutus & b 237 & v & \\
\hline
\end{tabular}

Only one record: one at Khaldeh pool on 2 April 1955 (Navins in Kumerloeve 1962).

\begin{tabular}{l|l|l|l|l|l}
\hline 26 & LC & Ruff & Calidris pugnax & حجو الة & PM, wv, s
\end{tabular}

Common to abundant passage migrant in mid-February-late May (chiefly March-April) and early Augustmid-November (chiefly September), principally in the Beqaa Valley, coast and estuaries. Scarce winter visitor, in late November-mid February, mainly to Cheikh Zennad and Palm Islands. Very small numbers oversummer at Cheikh Zennad in June - July (Bara in Ramadan-Jaradi \& Ramadan-Jaradi, 1999). Reported 
from Aammiq, Akkar, Beirut, Beqaa Valley, Borquael, Cheikh Zennad, Damour, Ehden, Naqoura, Palm Islands, Qaraoun and Tyre Coast. First recorded in 1878 by Van Dyck (Kumerloeve, 1962).

\begin{tabular}{|l|l|l|l|c|l|l|}
\hline & TS & English Name & Scientific Name & Arabic Name & $\begin{array}{l}\text { Phenologycal } \\
\text { Status }\end{array}$ & \\
\hline 27 & LC & Broad-billed Sandpiper & Calidris falcinellus & pm & \\
\hline
\end{tabular}

Scarce passage migrant. Recorded on 14 different dates between mid-April-late May and early August-early October 1996-2007, usually in small numbers varying between one and four, most at Cheikh Zennad, with a maximum of 18 there on 1 September 1996 (Bara, 1998) and to a lesser extent at Qaraoun, Palm Islands and Yammouneh (GR-J). First recorded in 1964 (Benson 1970).

\begin{tabular}{|l|l|l|l|l|l}
\hline 28 & LC & Jack Snipe & $\begin{array}{l}\text { Lymnocryptes } \\
\text { minimus }\end{array}$ & pm, wV \\
\hline
\end{tabular}

Rare passage migrant and scarce winter visitor from mid-October-late April, with records from Aammiq, Cheikh Zennad, Hermel, Kfar Zabad, Litani River Palm Islands and Qaraoun. Perhaps more common than records suggest. First recorded by Van Dyck in 1873 - 1878 (Kumerloeve 1960, 1962).

\begin{tabular}{|l|l|l|l|l|l|}
\hline 29 & NT & Great Snipe & Gallinago media & pm \\
\hline
\end{tabular}

Rare passage migrant mainly recorded in the Beqaa Valley (with most at Aammiq) and on Palm Islands, in mid-March-mid-May. Only four in autumn: one at Aammiq on 6 October 1956 (Kumerloeve 1962), one trapped at Aammiq on 14 September 1996 (Ramadan-Jaradi \& Ramadan-Jaradi 1999), one there on 11 October 2005 (A Rocha Lebanon 2006), and [one reported at Lake Qaraoun on 6 October 2006 - (see Balmer \& Betton (2007)]. Sighted at Aammiq, Beirut, Beqaa Valley, Faraya, Palm Islands, Qaraoun, and Tyre Coast. First recorded in 1881 by Van Dyck (Tristram in Kumerloeve (1962).

\begin{tabular}{l|l|l|l|l|l|l|l}
\hline 30 & LC & Common Snipe & Gallinago gallinago & الثنقب (الجهلول) الثائع & pm, wV
\end{tabular}

Uncommon but regular passage migrant and winter visitor from mid-August-mid May. Occurs over most of the country but favours the Aammiq area, Bishmezzine and Tyre Coast, principally in winter. Sighted at Aammiq, Al Quaser, Beirut, Beqaa Valley, Bishmezzine, Cheikh Zennad, Damour, Jounieh, Hermel, Kfar Zabad, Khaldeh, Palm Islands, Ras Baalbek, Ryaq and Tyre Coast. First recorded in 1904 (Carruthers, 1910).

\begin{tabular}{|l|l|l|l|r|l}
\hline 31 & LC & Terek Sandpiper & Xenus cinereus & pm \\
\hline
\end{tabular}

Five records from Cheikh Zennad area only: one on 18 August 1996 (Bara, 1998), one on 22 September 2002 (Ramadan-Jaradi et al., 2005), one on 6 September 2003 (Marc Almecija pers comm), and three on 7 and a single on 21 August 2005 (Colin Conroy pers comm). These records suggest that the Terek Sandpiper is a rare passage migrant rather than vagrant.

\begin{tabular}{l|l|l|l|r|l|l|}
\hline 32 & LC & Common Sandpiper & Actitis hypoleucos & طيطوي اعتيادي & PM, wv, s
\end{tabular}

Common passage migrant and scarce winter visitor. Recorded year-round at inland waters, coasts and on islands. Reported from Aammiq, Amyoun, Anjar, Batroun, Beirut, Cheikh Zennad, Dbaye, Damour, Enfeh, Jieh, Joub Jannine, Jounieh, Khaldeh, Litani, Ouzai, Palm Islands, Qaraoun,Tabarja and Tal El-Akdar. First recorded by Van Dyck in 1873-1878 (Kumerloeve 1960, 1962).

\begin{tabular}{|l|l|l|l|r|l|}
\hline 33 & LC & Green Sandpiper & Tringa ochropus & الطيطوي الأخضر & PM, WV
\end{tabular}

Fairly common passage migrant in late February-late June (most mid-March-mid-April) and late July-late October. Scarce winter visitor in November-February. Most at Cheikh Zennad, Palm Islands and at inland waters, including Aammiq; very few coastal records. Reported from Aammiq, Ain Zhalta, Anfeh, Beirut, Cheikh Zennad, Hermel, Hosh el Sayyed Ali, Jabal Mazar, Joub Jannine, Kfar Zabad, Laqlouq, Litani River, Maad, Ouzai, Palm Islands, Qaraoun and Tyre Coast. First recorded in 1877 by Van Dyck (Kumerloeve, 1962).

\begin{tabular}{|l|l|l|l|r|l|l|}
\hline & TS & English Name & Scientific Name & Arabic Name & $\begin{array}{l}\text { Phenologycal } \\
\text { Status }\end{array}$ & \\
\hline 34 & LC & Common Redshank & Tringa totanus & pm, wv & \\
\hline
\end{tabular}


Uncommon but regular passage migrant in March-April and commoner from early August-late December. Few overwinter at Cheikh Zennad and Palm Islands during January-February. Regular on Palm Islands and coasts, much less so at inland waters (Ramadan-Jaradi \& Ramadan-Jaradi, 1999). Sighted at Aammiq, Batroun, Beirut, Beqaa Valley, Bishmezzine, Byblos, Cheikh Zennad, Palm Islands, Qaraoun, Tripoli and Tyre. First recorded in 1904 (Carruthers, 1910).

\begin{tabular}{l|l|l|l|l|l|}
\hline 35 & LC & Marsh Sandpiper & Tringa stagnatilis & طبطوي البطائح & pm, ?wv
\end{tabular}

Uncommon passage migrant in early March-late April and early August-late October at coasts, estuaries and Palm Islands; and scarce at inland waters, including Aammiq. One winter record: at Al Ain near Tyre on 12 December 1996 (Ramadan-Jaradi \& Ramadan-Jaradi, 1999). Eleven records at Cheikh Zennad in April and August-November, with a maximum of 31 on 17 April 2006 (Colin Conroy pers. Comm.). First recorded by Tohmé \& Neuschwander (1974).

\begin{tabular}{l|l|l|l|r|l|}
\hline 36 & LC & Wood Sandpiper & Tringa glareola & طبطوي الغياض & PM
\end{tabular}

Fairly common passage migrant from mid-February-late May and late July-early November, on islands, coasts and inland wetlands. Sighted at Aammiq, Cheikh Zennad, Damour, Joub Jannine, Khaldeh, Litani, Palm Islands, Qaraoun and Tal Znoub. First recorded by Van Dyck in 1873-1878 (Kumerloeve, 1960, 1962).

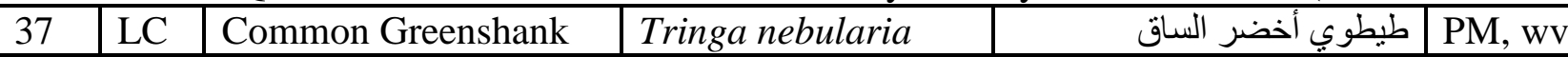

Relatively common passage migrant in March-April and late July-late October over much of the country. Very few in winter, from January-mid-February, in the Beqaa, principally at Qaraoun and the Litani River; and on the coast, principally at Cheikh Zennad and on Palm Islands. Sighted at Aammiq, Anjar, Beirut, Beqaa Valley, Cheikh Zennad, Damour, Litani River, Nahr Beirut, Naqoura, Palm Islands, Qaraoun, Tanayel and Tyre Coast. First recorded in 1877 by Van Dyck (Kumerloeve, 1962).

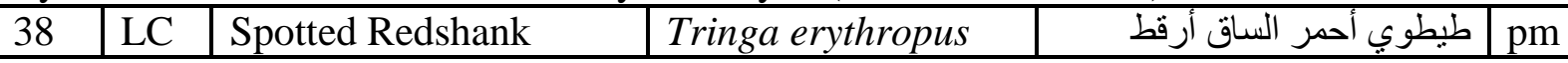

With 15 records, the Spotted Redshank is a scarce passage migrant rather than true vagrant. It occurred at Aammiq, Cheikh Zennad, Khaldeh and Nahr Beirut in March-April and July-September, with only one winter record at Cheikh Zennad on 19 January 2000 (Ramadan-Jaradi et al., 2005). Outside the range of its passage, one recorded on 19 July 2008 at Cheikh Zennad (Colin Conrey pers comm). First recorded in 1975 (Macfarlane, 1978).

\begin{tabular}{|l|l|l|l|l|l|}
\hline 39 & LC & Collared Pratincole & Glareola pratincola & أبو اليسر المطوق
\end{tabular}

Uncommon passage migrant in April-May and mid-August-early November, mostly on coasts and islands. Reported from Aammiq, Al Mansoura, Beirut, Cheikh Zennad, Chwaifat, Palm Islands and Ras Baalbek. First recorded in 1875 by Van Dyck (Kumerloeve, 1962).

\begin{tabular}{|l|l|l|l|l|l|l}
\hline 40 & NT & $\begin{array}{l}\text { Black-winged } \\
\text { Pratincole }\end{array}$ & Glareola nordmanni & pm \\
\hline
\end{tabular}

Uncommon to rare passage migrant in April-May and mid-September-early October on islands, coasts, low montane areas (Dalhoun) and at Aammiq (Ramadan-Jaradi \& Ramadan-Jaradi, 1999). All subsequent records fall within the above periods. Sighted at Aammiq, Cheikh Zennad, Dalhoun, Palm Islands, Ras Baalbek and Saida. First recorded in 1969 (Benson, 1970).

\section{ACKNOWLEDGEMENT}

This work was undertaken through a grant from the National Council for Scientific Research, Lebanon. Thanks, are extended to the Ministry of Environment of Lebanon and the IUCN for facilitating my work in the field, and to my dear friend Fouad Itani for his willingness to provide the photos of the birds recorded. 


\section{REFERENCES}

Balmer, D. \& K. Betton. (2001). Around the Region. Sandgrouse 23: 156-160.

Balmer, D. \& K. Betton. (2006). Around the Region. Sandgrouse 28: 90-96.

Balmer, D. \& K. Betton. (2007). Around the Region. Sandgrouse 29: 9-16.

Bara, T. (1998). Selected records from Cheikh Zennad, a coastal wetland in north-west Lebanon. Sandgrouse 20: 40-45.

Beale, CM \& A Sprenger. (2001). The Birds of the Aammiq Area. A Rocha 2000-2001 Report, Lebanon.

Benson, SV . (1970). Birds of Lebanon and the Jordan area. International Council for Bird Preservation, Cambridge and Warne, London, UK.

Birdlife International. (2018). What are seabirds? https://www.birdlife.org/europe-andcentral-asia/seabirds-and-marine-what-are-seabirds

Blondel, J., Ferry, C., \& Frochot, B. (1981). Point counts with unlimited distance. Studies in Avian Biol., 6, 414-420.

Busuttil, S., \& Flumm, D. (1998). Seawatching at Ras Beirut, Lebanon in spring 1997. Sandgrouse, 20, 142-143.

Carruthers, D. (1910). On a collection of birds from the Dead Sea and north-western Arabia, with contributions to the ornithology of Syria and Palastine. Ibis (IX) 4: 475-491.

Cawkell, E. M. (1944). Notes on some birds in the Beirut area littoral. Bull. Zool. Soc. Egypt, Syria-Palest. Suppl. 6, 23-25.

Cramp, S. (ed). (1985). The Birds of the Western Palearctic, (4), OUP, Oxford, UK.

Evans, MI. (1994). Important Bird Areas in the Middle East. BirdLife Conservation Series. No 2. BirdLife International, Cambridge, UK.

Flash, B. (1959). Höstobservationer i Libanon. Fauna och Flora 1959: 161-180.

Hemprich, FG. \& CG. Ehrenberg. (1833). Symbolae Physica seu Icones et Descriptiones Avium quae ex itinere per Africam Borealem et Asiam Occidentalem. Berlin. Germany.

Hollom, P. A. D. (1959). Notes from Jordan, Lebanon, Syria and Antioch. Ibis, 101, 183200.

Kirwan, GM. (1997). Around the Region. Sandgrouse 19: 156-160.

Kirwan, GM. (2001). Around the Region. Sandgrouse 23: 76-80.

Kumerloeve, H. (1960). The Bird-Collection of W. Th. Van Dyck (1857-1939) in the museum of the American University of Beirut. Alauda 28-2: 124-128.

Kumerloeve, H. (1962). Notes on the birds of the Lebanese Republic. Iraq Nat. Hist. Mus. Publ. 20 (21), 1-81.

Macfarlane, A. M. (1978). Field notes on the birds of Lebanon and Syria, 1974-1977. Army Bird-watching Soc. Per. Publ. 3.

MOE, IUCN, UN Environment \& GEF (2018). Assessment of the Management Effectiveness of Marine Protected Areas in Lebanon. Terms of Reference. "Policy and Legislative Development for Mainstreaming the Sustainable Management of Marine and Coastal Ecosystems in Lebanon" Project.

Nevins, J. (1960). Partial check-list of the birds of Lebanon. Unpubl. manuscript.

Ramadan-Jaradi, G., \& Ramadan-Jaradi, M. (1997). Notes on some breeding birds of Lebanon. Sandgrouse, 19, 122-125.

Ramadan-Jaradi, G., \& Ramadan-Jaradi, M. (1999). An updated checklist of the birds of Lebanon. Sandgrouse, 21, 132-170. 
Ramadan-Jaradi, G., \& Ramadan-Jaradi, M. (2001). The avifauna of Palm Islands Nature Reserve in Lebanon 1893-2000. Lebanese Science Journal, 2(1), 17-35.

Ramadan-Jaradi, G., \& Ramadan-Jaradi, M. (2002). Population size of the Syrian Serin Serinus syriacus and other ornithological records from Lebanon. Lebanese Science Journal, 3(1), 27- 35.

Ramadan-Jaradi, G. \& J. Waterbury (2002). Notes on the birds of Cheikh Zennad. Unpubl. Manuscript.

Ramadan-Jaradi, G., Bara, T., Al-Mecija, M., \& Ramadan-Jaradi, M. (2004). Significant bird notes from Lebanon during 2002-2003. Sandgrouse, 26(1), 29-34.

Ramadan-Jaradi, G., Waterbury S. P., \& Ramadan-Jaradi, M. (2005). Ornithological observations from Lebanon during 2003-2004. Sandgrouse, 27(1), 69-73.

Ramadan-Jaradi, G. (2006). Status of Marine and Coastal bird species in Lebanon. Proceeding of the first symposium on the Mediterranean Action Plan for the conservation of marine and coastal birds. UNEP; MAP; RAC/SPA. Oct. 2006.

Ramadan-Jaradi, G., Bara, T., \& Ramadan-Jaradi, M. (2008). Revised checklist of the birds of Lebanon 1999-2007. Sandgrouse, 30(1), 22-69.

Ramadan-Jaradi, G. (2010). Rehabilitation of Economic Functions of War-damaged Palm Islands Nature Reserve (PINR) Lebanon. Obtained on 20/12/2010 the Prize of KSA for the best environmental management in Arab countries that was organized by the Arab League States.

Ramadan-Jaradi, G. (2017a). Status and Distribution of Migrating and breeding sea birds in north Lebanon. Lebanese Science Journal, 18(2).

Ramadan-Jaradi, G. (2017b). National Monitoring Programme for Biodiversity in Lebanon - EO1 - Seabirds. Developed for Ecap and MedMPA net II Lebanon.

Ramadan-Jaradi, G. (2017c). Training on the identification of the marine birds with focusing on threatened and endangered species. Supported by RAC-SPA, 2017.

Ramadan-Jaradi, G. (2017d). National Monitoring Programme for Biodiversity in Lebanon - EO1 - Seabirds, Study Report on behalf of SPA-RAC/Barcelona Convention. Tunisia.

Ramadan-Jaradi, G., \& Itani, F. (2018). Two new species for Lebanon, White headed Duck Oxyura leucocephala and Eyebrowed Thrush Turdus obscurus, and two other interesting records for Lebanon.

Schrader, G. (1892). Ornithologische Beobachtungen auf meinen Sammelreisen. III. Syrien. Orn. Jhrb. 3: 11-17.

Steele, J. (2008). Encyclopedia of Ocean Sciences, Second Edition. Academic Press. ISBN: 978-0-12-374473-9.

Stenhouse, J. H. (1904). The birds of Nakhl island on the coast of Syria. Ibis (VIII), 4, 2932.

Tohmé, G., \& Neuschwander, J. (1974). Nouvelles données sur l'avifaune de la République Libanaise. Alauda, 13, 243-258.

Tristram, HB. (1864). Report on the birds of Palestine. Proc. Zool. Soc. London 426456.

Tristram, HB. (1882). Ornithological notes of a journey through Syria, Mesopotamia, and southern Armenia in 1881. Ibis 6(IV), 402-419.

Tully, J. r., Dorresrein, G., Jones, A., \& Cooper, J. (2009). Handbook of Avian Medicine. $2^{\text {nd }}$ Edition. Saunders Ltd.

West, D (1954). Nature notes from the Lebanon. Toronto Field Natur. Club 126: 1-11. 